\title{
Isolation and characterization of fowl adenovirus serotype 4 from chickens with hydropericardium syndrome in Korea
}

\author{
Hong-Su Park ${ }^{1}$, Il-Soo Lim ${ }^{1}$, Sang-Kyu Kim ${ }^{1}$, Toh-Kyung Kim², Sang-Geon Yeo,* \\ ${ }^{1}$ College of Veterinary Medicine, Kyungpook National University, Daegu 702-701, Korea \\ ${ }^{2}$ Gyeongnam Livestock Promotion Institute, Jinju 660-985, Korea
}

(Received: July 27, 2011; Revised: September 28, 2011; Accepted: September 28, 2011)

\begin{abstract}
Four strains of fowl adenovirus (FAdV) were isolated from 4 flocks of broiler or layer chickens affected by hydropericardium syndrome in Korea. These FAdVs were classified as serotype 4 by restriction fragment length polymorphism patterns of hexon genes and whole genomes. The virus exhibited cytopathic effects consisting of rounding, ballooning and clustering in primary chicken embryo liver cell cultures. In transmission electron microscopy, virus particles in hexagonal shape aggregated exclusively in the nuclei of hepatocytes of the chickens as the typical appearances in adenovirus infections. Buoyant density of the virus in cesium chloride $(\mathrm{CsCl})$ was $1.34 \mathrm{~g} / \mathrm{mL}$. The virus was stable to chloroform, ether, $50 \sim 70 \%$ ethanol, acidic condition at $\mathrm{pH} 3,0.25 \%$ trypsin $(1: 250)$, heat at $50^{\circ} \mathrm{C}$ for $30 \mathrm{~min}$, but labile to $100 \%$ ethanol, heat at $52 \sim 60^{\circ} \mathrm{C}$ for $30 \mathrm{~min}, 1 \mathrm{M} \mathrm{MgCl}_{2}$ at $50^{\circ} \mathrm{C}$ for $1 \mathrm{~h}, 1: 2,000$ formalin (37\%). All of the physicochemical properties pertained to the characteristics of adenoviruses. Eight viral polypeptides were determined in CsCl-purified virus by sodium dodecyl sulfate-polyacrylamide gel electrophoresis.
\end{abstract}

Keywords : adenovirus properties, fowl adenovirus, polypeptides, RFLP patterns

\section{Introduction}

Fowl adenoviruses (FAdVs) are classically designated as group I avian adenoviruses and infect many kinds of poultry including chickens, turkeys, ducks and geese. FAdVs belong to the genus Aviadenovirus of the family Adenoviridae, and there are 5 species, FAdV A to $\mathrm{E}$ according to their genotypes. Twelve serotypes are known and grouped into 5 species based on their crossneutralization $[2,3,14]$. Recently, restriction endonuclease analysis along with polymerase chain reaction (PCR) is used to differentiate serotypes of the FAdVs [2, 3, 9, 17, 22, 26]. The FAdV virion is non-enveloped and icosahedral, and it has hexon, penton base and fiber as major capsid proteins [2, 3, 14]. Hexon is the major antigenic determinant and its nucleotide sequence has been used not only for phylogenic analyses but serotyping by PCR and restriction fragment length polymorphism (RFLP) [2, 3, 9, 15, 17, 18, 22].

While various FAdV serotypes are isolated from diseases such as inclusion body hepatitis (IBH) and respiratory distress as potential pathogens, fowl adenovirus serotype 4 (FAdV-4), which belongs to FAdV C, is exclusively isolated from most cases of hydropericardium syndrome (HPS) as a primary pathogen [2, 3, 10]. HPS with hepatitis is a recent problematic disease of economic importance in broiler, breeder and layer chickens with high mortality up to $75 \%$. After the first report on the outbreaks of HPS in Angara Goth, Pakistan in 1987 [4], the disease has occurred in many countries in Western and South Asia, South and Central America, Russia and Japan [1-3]. In Korea, HPS was first reported in chickens by the methods of histopathology, gene detection or transmission electron microscopy in 2007 [7, 12]. Kim et al. [11] also reported HPS outbreaks by histopathology and gene detection as well as virus isolation, although properties of the virus were unclear. Recently, HPS has occurred in many regions in Korea, and, therefore, biological and physicochemical properties of FAdV isolates should be fully determined for the

\footnotetext{
*Corresponding author

Tel: +82-53-950-5968, Fax: +82-53-950-5955

E-mail: sgyeo@knu.ac.kr
} 
epidemiology and effective control of the disease.

In the present study, trials were done for the isolation and characterization of FAdV from HPS outbreaks in Korea, to offer the viral properties for epidemiological studies and control of FAdV infections.

\section{Materials and Methods}

\section{Samples for gene detection and virus isolation}

For the isolation of FAdV, liver tissues were collected from chickens suspected of HPS in 3 broiler farms located in Changnyeong (Gyeongnam province), Andong (Gyeongbuk province) and Yeoju (Gyeonggi province), and a layer farm in Gunwi (Gyeongbuk province), Korea between January, 2008 and June, 2010. These chickens were 16 20 days old broilers and 70 days old layers with no history of vaccinations against FAdVs. The chickens clinically showed depression and death with mortality rates of $5 \sim 10 \%$. At necropsy, gross lesions of hydropericardium and enlarged, partially amber-colored livers were observed.

\section{Detection of FAdV hexon genes}

For detection of FAdV genes, 10\% homogenates of the chicken liver tissues were prepared in minimum essential medium (WelGene, Korea). DNA was extracted from the homogenates using Viral Gene-spin kit (iNtRON Biotechnology, Korea) and used for PCR. Primers were designed according to the suggestion by Raue and Hess [22], which can detect DNA with 1,319 bases from whole hexon gene of FAdV. Nucleotide sequence of the sense primer was 5'AACGTCAA CCCCTTCAACCACC 3 ' and that of the antisense primer was 5'TTGCCTGTGGCGAAAGGCG3'. PCR was done with rTaq DNA polymerase (Elpis-biotech, Korea) under conditions of initial denaturation at $94^{\circ} \mathrm{C}, 4$ min followed by 30 cycles of each $1 \mathrm{~min}$ at $94^{\circ} \mathrm{C}, 50^{\circ} \mathrm{C}$ and $72^{\circ} \mathrm{C}$, and final extension at $72^{\circ} \mathrm{C}, 5 \mathrm{~min}$. Target DNAs were detected by gel electrophoresis with $1 \%$ UltraPure agarose (Invitrogen, USA) and $1 \mathrm{Kbp}$ plus $100 \mathrm{bp}$-DNA ladder marker (Elpis-biotech, Korea).

\section{Electron microscopic examination}

The chicken liver tissues were trimmed to $8 \sim 10 \mathrm{~mm}^{3}$. After washed 3 times with $0.2 \mathrm{M}$ phosphate buffered saline (PBS) (Sigma, USA), the tissues were fixed with $2.5 \%$ glutaraldehyde (Sigma, USA) for pre-fixation. While at $4^{\circ} \mathrm{C}$ for $2 \mathrm{~h}$, the tissues were gently stirred every $10 \mathrm{~min}$. Then the tissues were poured on a Petri dish and incubated at room temperature for $10 \mathrm{~min}$, and stored in $0.2 \mathrm{M} \mathrm{PBS}$ at $4^{\circ} \mathrm{C}$. These were post-fixed with $1 \%$ osmium tetroxide at $4^{\circ} \mathrm{C}$ for $1 \mathrm{~h}$ and washed in PBS. The tissues were dehydrated through a graded series of ethanol and substituted with propylene oxide, and then embedded in Epon 812 at $60^{\circ} \mathrm{C}$ for 48 h. Sections $(<90$ $\mathrm{nm}$ ) were cut on an ultramicrotome (Leica, Germany) using a diamond knife (Diatome, Switzerland). The ultrathin sections were transferred on to 200 mesh copper grids and stained with uranyl acetate for $20 \mathrm{~min}$, and with lead citrate for further $10 \mathrm{~min}$. The sections were examined for FAdV particles under transmission electron microscope (Hitachi, Japan) at $80 \mathrm{kV}$.

\section{Virus isolation}

Liver tissues from 14-day old embryonated hen's eggs were minced and digested using $0.05 \%$ trypsin-EDTA (Invitrogen, USA) to produce primary chicken embryo liver (CEL) cells. After trypsin was neutralized by newborn calf serum (NBCS) (Invitrogen, USA), cells were centrifuged and resuspended twice. The cells were cultured, using medium 199 (M199; Invitrogen, USA) supplemented with $5 \%$ NBCS, penicillin $(100 \mathrm{U} / \mathrm{mL})$ and streptomycin $(100 \mu \mathrm{g} / \mathrm{mL}$; Invitrogen, USA), in a $5 \% \mathrm{CO}_{2}$ incubator at $37^{\circ} \mathrm{C}$. A day later, the CEL cells were used for FAdV isolation, while mock-infected CEL cells were confirmed for FAdV-negative by PCR using the primers for hexon gene. The mock-infected cells also were checked for latent FAdVs through two passages as suggested by Adair and McFerran [3], from which no cytopathic effects (CPEs) induced by the latent virus were observed.

$100 \mu \mathrm{L}$ of the liver tissue homogenates made from HPS-suspected chickens were inoculated into CEL cells grown in $25-\mathrm{cm}^{2}$ tissue culture flasks, and viral propagation was determined by the appearance of CPEs. After CPEs developed prominently, the cells were frozen and thawed 3 times, and propagated FAdV was confirmed by PCR for hexon gene. Viral fluid was harvested by centrifugation at $4,000 \mathrm{rpm}, 20 \mathrm{~min}$ and stored at $-70^{\circ} \mathrm{C}$ for further use.

Titration of tissue culture infectious dose 50 (TCID $\left._{50}\right)$ After 4th passage of the virus isolate in CEL cell cultures, viral fluid was filtered with $0.22 \mu \mathrm{m}$ membrane filter (Millipore, USA). The virus was ten-fold diluted and inoculated into CEL cell cultures of 96-well tissue 
culture plates to determine the titer of $\mathrm{TCID}_{50}$ by the Reed-Muench method. Virus of known TCID $_{50}$ was then used for the determination of viral physicochemical properties.

\section{Determination of physicochemical properties}

Buoyant density of virus in cesium chloride $(\mathrm{CsCl})$ : The viral fluid was ultracentrifuged at 45,000 rpm (ultracentrifuge XL-100; Beckman, USA), $4^{\circ} \mathrm{C}$ for $16 \mathrm{~h}$ after clarified by low-speed centrifugation. The pellet was resuspended in sterile $0.85 \%$ saline and layered on a cushion of $25 \sim 50 \% \mathrm{CsCl}$ (Amresco, USA), and ultracentrifuged at $45,000 \mathrm{rpm}, 4^{\circ} \mathrm{C}$ for $16 \mathrm{~h}$. Buoyant density of the viral band was measured and the virus in the $\mathrm{CsCl}$ solution was ultracentrifuged to obtain purified virus. PCR for hexon gene was also done to confirm FAdV from purified virus and the target DNA was detected by gel electrophoresis with $1 \mathrm{Kbp}$ plus $100 \mathrm{bp}$-DNA ladder marker.

Sensitivity to chloroform: $1 \mathrm{~mL}$ of viral fluid was added with $0.5 \mathrm{~mL}$ of chloroform (Merck, Germany) and shaken for $10 \mathrm{~min}$ at room temperature. After centrifuged at 2,000 rpm, for $10 \mathrm{~min}$, the supernatant was ten-fold diluted with M199 and cultured in CEL cells [23].

Sensitivity to ether: $1 \mathrm{~mL}$ of viral fluid was mixed with $0.2 \mathrm{~mL}$ of ethyl ether (Fischer Scientific, USA) and incubated at $4^{\circ} \mathrm{C}$ for $18 \mathrm{~h}$. Then it was poured onto a Petri dish and kept at room temperature for $20 \mathrm{~min}$ to evaporate the ether. It was ten-fold diluted and cultured in CEL cells [25].

Sensitivity to ethanol: Each $1 \mathrm{~mL}$ of viral fluid was mixed with $0.5 \mathrm{~mL}$ of 50,70 and $100 \%$ ethanol (Merck, Germany), respectively. Then they were incubated at room temperature for $1 \mathrm{~h}$. After poured onto a Petri dish, they were left at room temperature for $30 \mathrm{~min}$. Each viral fluid was cultured in CEL cells after ten-fold dilution [23].

Sensitivity to formalin: Formaldehyde (37\%; Sigma, USA) was diluted to $1: 2,000$ with distilled water and mixed with an equal volume of viral fluid. After incubation at $37^{\circ} \mathrm{C}$ for $17 \mathrm{~h}$, the mixture was ten-fold diluted and cultured in CEL cells [23].

Sensitivity to trypsin: Trypsin ( 1 : 250; Difco, USA) was dissolved in distilled water to make $0.25 \%(\mathrm{w} / \mathrm{v})$, and viral fluid was diluted to 1 : 10 with PBS (WelGene, Korea). Equal volumes of virus and trypsin were mixed and incubated at $37^{\circ} \mathrm{C}$ for $30 \mathrm{~min}$, followed by cooling on ice for $5 \mathrm{~min}$. The mixture was ten-fold diluted and cultured in CEL cells [21].

Sensitivity to acidic pH: Viral fluid was ten-fold diluted with $\mathrm{M} 199$ which was acidified with $\mathrm{HCl}$ to $\mathrm{pH}$ 3. After incubation at $37^{\circ} \mathrm{C}$ for $1 \mathrm{~h}$, the $\mathrm{pH}$ was recovered by adding sodium bicarbonate, and it was cultured in CEL cells [23].

Sensitivity to heat: Viral fluid was ten-fold diluted with M199 and incubated for $30 \mathrm{~min}$ at 50, 52, 54, 56, and $60^{\circ} \mathrm{C}$, respectively. Then each of the diluted virus was cultured in CEL cells [23].

Thermo-inactivation by $\mathbf{M g C l}_{\mathbf{2}}$ : Viral fluid was diluted to $1: 10$ with $\mathrm{M} 199.100 \mu \mathrm{L}$ of the diluted viral fluid were mixed with an equal volume of $2 \mathrm{M} \mathrm{MgCl}_{2}$ (Sigma, USA) and incubated at $50^{\circ} \mathrm{C}$ for $1 \mathrm{~h}$, then cooled on ice for $5 \mathrm{~min}$. After ten-fold dilution, it was cultured in CEL cells [21].

\section{Serotyping by RFLP patterns}

Viral DNAs extracted from 10\% liver tissue homogenates of HPS-suspected chickens were used for the amplification of FAdV hexon gene by PCR. PCR was done with the same conditions as in the detection of FAdV hexon genes. The amplified hexon gene DNAs were purified by QIAquick Gel Extraction kit (Qiagen, Germany). Based on the method of Raue and Hess [22], the DNAs were digested with restriction enzyme HpaII (Elpis-biotech, Korea) and run on a 3\% agarose gel with 50 bp-DNA ladder marker (Solgent, Korea). RFLP patterns of the DNAs were analyzed to classify serotypes of FAdVs.

Further attempts were made to determine serotypes by RFLP patterns in whole genomes of the FAdV isolates, based on the method of Zsák and Kisary [26]. Virus was harvested from propagated CEL cells and subjected to concentration with polyethylene glycol (Sigma, USA). Whole genomic DNAs were extracted with DNA extraction buffer (10 mM tris- $\mathrm{HCl}, 10 \mathrm{mM}$ EDTA, 100 $\mathrm{mM} \mathrm{NaCl}, 0.5 \%$ SDS, 2\% 2-mercaptoethanol, $1.25 \mathrm{mg} /$ $\mathrm{mL}$ proteinase $\mathrm{K}$ ) and precipitated with $3 \mathrm{M}$ sodium acetate and $100 \%$ ethanol. DNAs were digested with BamHI (New England Biolabs, USA) and run on a $0.8 \%$ agarose gel with $1 \mathrm{Kbp}$ plus $100 \mathrm{bp-DNA}$ ladder marker.

\section{Polypeptide patterns}

To analyze polypeptide patterns of the virus isolates, CsCl-purified virus was subjected to sodium dodecyl sulfate-polyacrylamide gel electrophoresis (SDS-PAGE) under reduced conditions. $9 \mu \mathrm{L}$ of the virus were mixed 
with an equal volume of sample buffer (1\% bromophenol blue, $10 \%$ SDS, $0.5 \mathrm{M}$ tris- $\mathrm{HCl}$, glycerol) with $10 \%$ 2-mercaptoethanol. From FAdV-infected CEL cells and mock-infected CEL cells, total protein was extracted with RIPA buffer ( $150 \mathrm{mM} \mathrm{NaCl}, 50 \mathrm{mM}$ tris-HCl, $0.1 \%$ SDS, $0.5 \%$ deoxycholic acid, $1 \%$ NP-40) and mixed with sample buffer. These samples were boiled at $100^{\circ} \mathrm{C}$ for $5 \mathrm{~min}$ and cooled on ice for $10 \mathrm{~min}$, and were run on a $12 \%$ polyacrylamide gel with ProSieve Color Protein Markers (Lonza, USA). The gel was stained with $0.1 \%$ Coomassie brilliant blue (Sigma, USA) for observation.

\section{Results}

\section{Detection of FAdV genes}

DNAs with $1,319 \mathrm{bp}$ specific to the hexon gene of FAdV were detected by PCR from the liver tissues in chickens suspected of HPS by clinical signs and gross lesions (Fig. 1). Therefore, the disease in these chickens from 4 farms was molecularly diagnosed as FAdV infection, and these strains were named as Kr-Changnyeong, Kr-Andong, Kr-Gunwi and $\mathrm{Kr}$-Yeoju according to the locations of the farms.

\section{Viral morphology by transmission electron micros- copy}

Typical adenovirus particles $(60 \sim 80 \mathrm{~nm}$ in diameter) aggregated in crystalline arrays in the nuclei of hepatocytes were observed from all of the HPS-suspected chickens. The particles showed spherical shape, rather close to the hexagonal appearance as the general features of adenoviruses (Fig. 2).

\section{Isolation of FAdVs}

While liver tissue homogenates from 4 chickens which were diagnosed as HPS by PCR were cultured in CEL cells, CPEs were observed 1 3 days post-infection. Those were nuclear degeneration, rounding, ballooning and clustering, which progressed to complete cell detachment 4 5 days post-inoculation (Fig. 3).

The viruses were harvested from the culture supernatant and further cell-passaged. After 4th passage, titers of the virus isolates were $10^{566} \sim 10^{70} \mathrm{TCID}_{50} / \mathrm{mL}$. For further

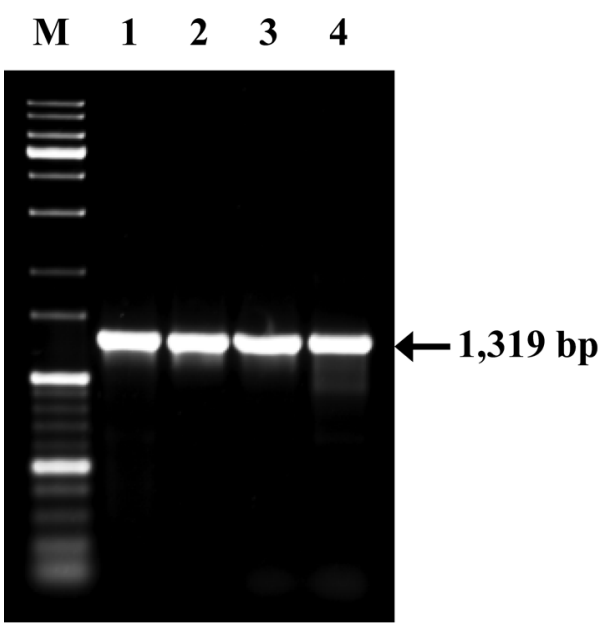

Fig. 1. Hexon gene DNAs of fowl adenoviruses (FAdVs) detected from liver tissue homogenates of HPS-suspected chickens. 1: Kr-Changnyeong strain, 2: Kr-Andong strain, 3: Kr-Gunwi strain, 4: Kr-Yeoju strain, M: $1 \mathrm{Kbp}$ plus 100 bp-DNA ladder marker.
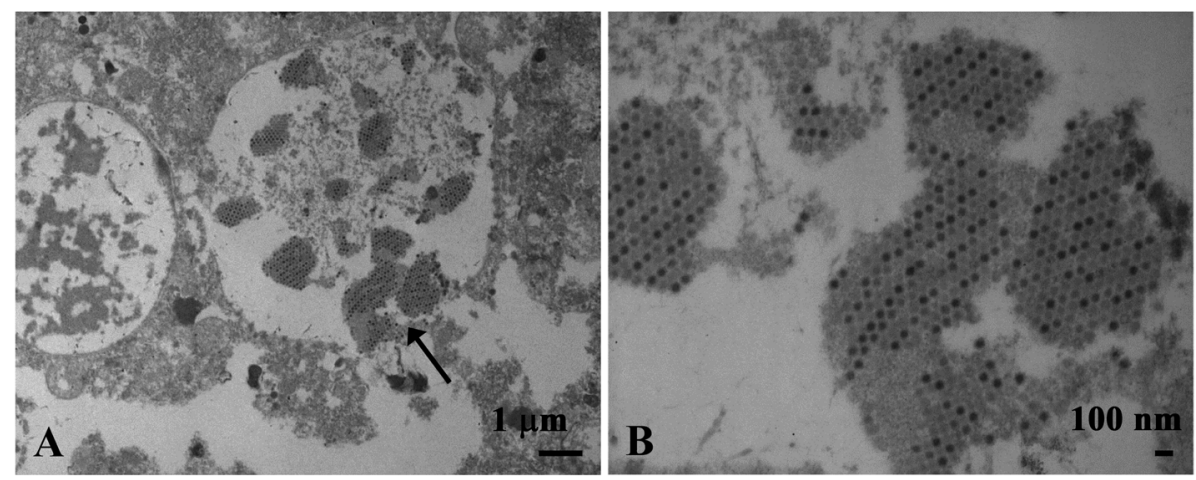

Fig. 2. Crystalline arrays of virus particles observed in the nuclei of hepatocytes of chickens diagnosed as hydropericardium syndrome. (A) isometric virus particles aggregated exclusively in the nucleus. Transmission electron microscope, $\times 6,000$. (B) virus particles in spherical, rather hexagonal shape observed by magnifying the area indicated with an arrow in (A). $\times 25,000$. 

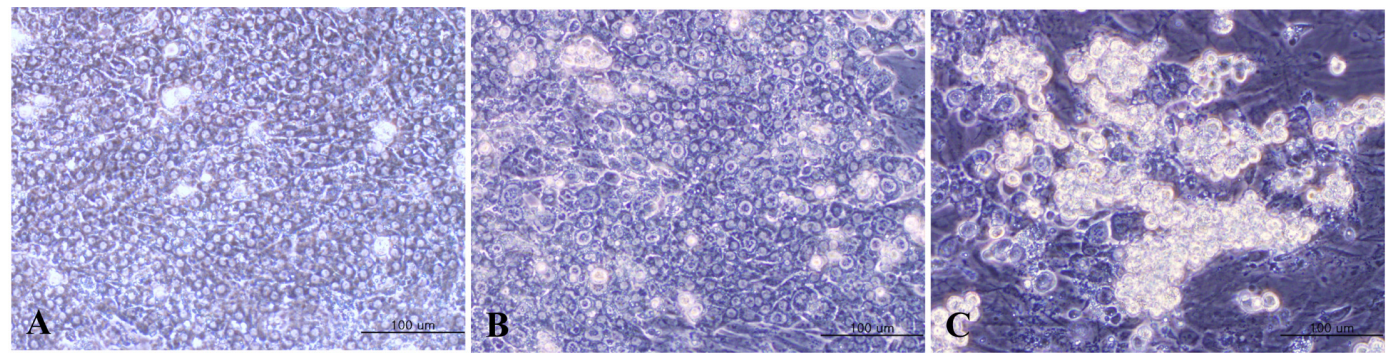

Fig. 3. Cytopathic effects (CPEs) with rounding, ballooning and clustering observed in CEL cells during virus propagation. (A) mock-infected CEL cells, 3 days. (B) virus-infected CEL cells, 2 days post-infection. (C) virus-infected CEL cells, 3 days post-infection. $\times 400$.

Table 1. Physicochemical properties of fowl adenovirus isolates

\begin{tabular}{lcc}
\hline \hline \multicolumn{1}{c}{ Treatment } & $\begin{array}{c}\text { Virus titers }\left(\mathrm{TCID}_{50} / \mathrm{mL}\right) \\
\text { after treatment }\end{array}$ & Properties of isolates \\
\hline Chloroform, room temperature, $10 \mathrm{~min}$ & $10^{6.5}$ & Stable \\
Ether, $4^{\circ} \mathrm{C}, 18 \mathrm{~h}$ & $10^{6.5}$ & Stable \\
Ethanol, room temperature, $1.5 \mathrm{~h}$ & & \\
$50 \%$ & $10^{6.33}$ & Stable \\
$70 \%$ & $10^{6.5}$ & Stable \\
$100 \%$ & $10^{4.66}$ & Labile \\
Acidic condition at $\mathrm{pH} 3,37^{\circ} \mathrm{C}, 1 \mathrm{~h}$ & $10^{6.5}$ & Stable \\
Trypsin $(0.25 \%), 37^{\circ} \mathrm{C}, 30 \mathrm{~min}$ & $10^{6.13}$ & Stable \\
Heat & & \\
$50^{\circ} \mathrm{C}, 30 \mathrm{~min}$ & $10^{6.33}$ & Stable \\
$52^{\circ} \mathrm{C}, 30 \mathrm{~min}$ & $10^{4.66}$ & Labile \\
$54^{\circ} \mathrm{C}, 30 \mathrm{~min}$ & $10^{3.5}$ & Labile \\
$56^{\circ} \mathrm{C}, 30 \mathrm{~min}$ & $<10^{1.0}$ & Labile \\
$60^{\circ} \mathrm{C}, 30 \mathrm{~min}$ & $<10^{1.0}$ & Labile \\
$\mathrm{MgCl}_{2}(1 \mathrm{M}), 50^{\circ} \mathrm{C}, 1 \mathrm{~h}$ & $<10^{1.0}$ & Labile \\
$1: 2,000$ formalin $(37 \%), 37^{\circ} \mathrm{C}, 17 \mathrm{~h}$ & $<10^{1.0}$ & Labile \\
\hline
\end{tabular}

${ }^{*}$ Virus with $10^{6.5} \mathrm{TCID}_{50} / \mathrm{mL}$ was used in chemical and heat treatments.

studies, Kr-Gunwi strain was selected as a representative among 4 isolates and subjected to the determination of physicochemical properties.

\section{Physicochemical properties of FAdV isolates}

An opaque viral band was observed in $\mathrm{CsCl}$-gradient (25 50\%) centrifugation. Buoyant density of the band was measured as $1.34 \mathrm{~g} / \mathrm{mL}$ which is a feature of adenoviruses. A DNA with $1,319 \mathrm{bp}$ specific to hexon gene of FAdV was also confirmed from this band by PCR (Fig. 4).

The virus $\left(10^{6.5} \mathrm{TCID}_{50} / \mathrm{mL}\right)$ was stable to chloroform, ether, $50 \sim 70 \%$ ethanol, acidic condition at $\mathrm{pH} 3,0.25 \%$ trypsin $(1: 250)$, and $50^{\circ} \mathrm{C}$ for $30 \mathrm{~min}$. On the other hand, it was moderately labile to $100 \%$ ethanol and heat at $52 \sim 54^{\circ} \mathrm{C}$ for $30 \mathrm{~min}$ with $\mathrm{TCID}_{50}$ titers reduced to $10^{466}$ or $10^{35}$ and completely labile to heat at $56-60^{\circ} \mathrm{C}$ for $30 \mathrm{~min}, 1 \mathrm{M} \mathrm{MgCl}_{2}$ at $50^{\circ} \mathrm{C}$ for $1 \mathrm{~h}$ and $1: 2,000$ formalin $(37 \%)$ with $\mathrm{TCID}_{50}$ titers reduced to $<10^{1.0}$ (Table 1).

\section{Serotype of FAdV isolates by RFLP patterns}

RFLP patterns by HpaII digestion of hexon gene DNAs (1,319 bp) detected from liver tissues by PCR, from which 4 FAdVs were isolated, exhibited 5 fragments ranged 460, 280, 230, 190 and $140 \mathrm{bp}$ in size (Fig. 5). These features were recognized as the RFLP patterns of FAdV-4 [10, 22]. 


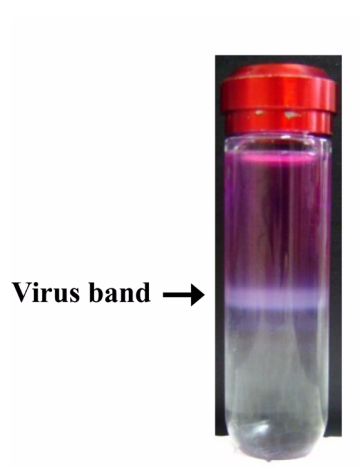

A

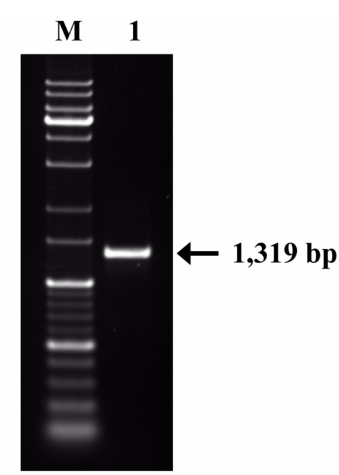

B
Fig. 4. A unique viral band observed in cesium chloride (CsCl)-gradient $(25 \sim 50 \%)$ centrifugation from which hexon gene was detected by PCR. (A) a virus band with buoyant density of $1.34 \mathrm{~g} / \mathrm{mL}$. (B) 1: a hexon DNA with $1,319 \mathrm{bp}$, M: $1 \mathrm{Kbp}$ plus 100 bp-DNA ladder marker.

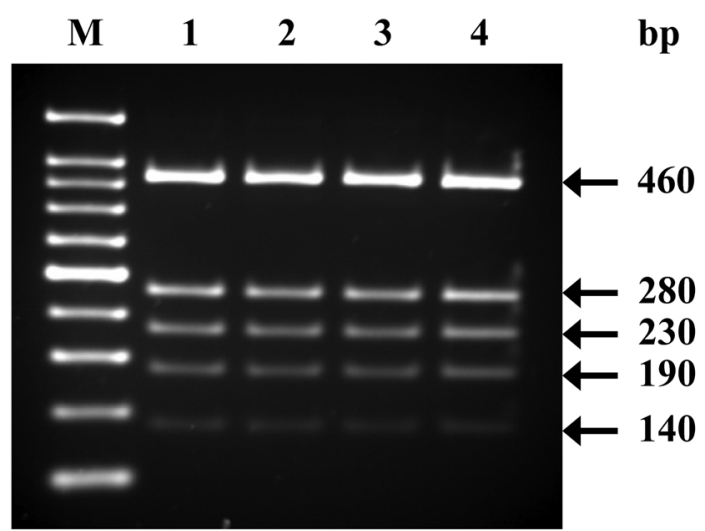

Fig. 5. Restriction fragment length polymorphism (RFLP) patterns of 4 FAdV isolates by HpaII digestion of hexon gene DNAs. 1: Kr-Changnyeong strain, 2: Kr-Andong strain, 3: Kr-Gunwi strain, 4: Kr-Yeoju strain, M: 50 bpDNA ladder marker.

In RFLP patterns by BamHI digestion of whole genomic DNAs in 4 FAdV isolates from CEL cell culture supernatant, all of the isolates showed 9 fragments ranged 1.8 to $8.8 \mathrm{kbp}$ in size (Fig. 6). These were also recognized as the RFLP patterns of FAdV-4 $[10,26]$. Therefore, all of 4 isolates were determined as FAdV-4.

\section{Polypeptide patterns of FAdV isolates}

The CsCl-purified virus showed approximately 8 polypeptide bands with molecular weights 180, 160, 110, $90,80,55,43$ and $23 \mathrm{kDa}$, which were distinguished from

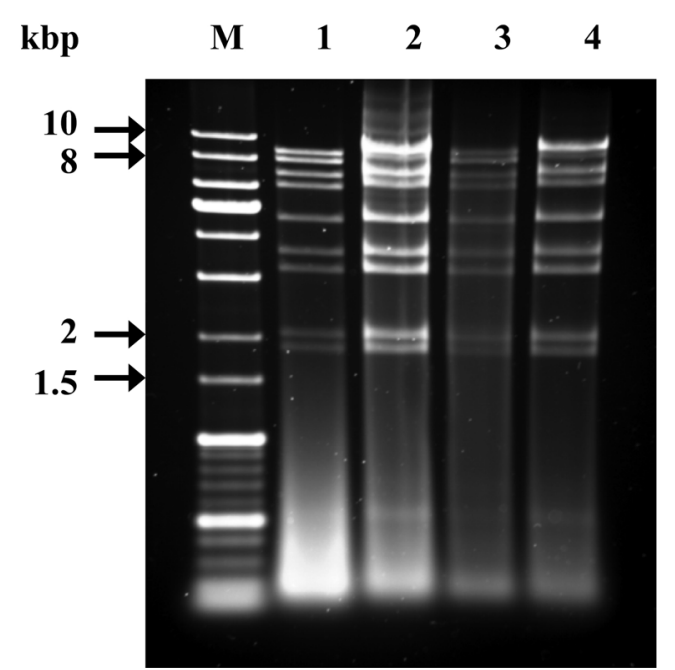

Fig. 6. RFLP patterns of 4 FAdV isolates by BamHI digestion of whole genomes. 1: Kr-Changnyeong strain, 2: Kr-Andong strain, 3: Kr-Gunwi strain, 4: Kr-Yeoju strain, M: $1 \mathrm{Kbp}$ plus $100 \mathrm{bp}$-DNA ladder marker.

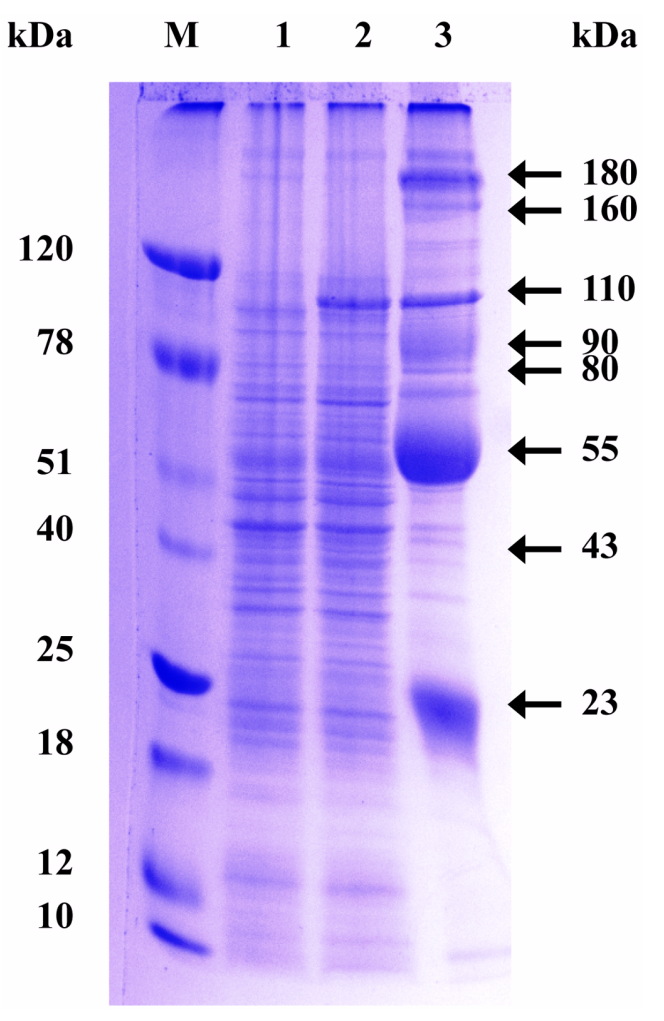

Fig. 7. Polypeptide bands of the FAdV isolate determined by SDS-PAGE. 1: mock-infected CEL cells, 2: FAdVinfected CEL cells, 3: FAdV purified by CsCl-gradient ultracentrifugation, M: ProSieve Color Protein Markers. 
peptide bands in mock-infected CEL cells by SDSPAGE analysis (Fig. 7).

\section{Discussion}

Four strains of FAdVs were isolated from livers of chickens affected by HPS, and these Korean FAdVs showed prominent CPEs including rounding, ballooning and clustering of the CEL cells, which were unclear before but determined in the present study. The virus particles revealed typical hexagonal shape in hepatocytes of the chickens as generally shown in adenovirus infections [1, 6, 8, 24, 25].

Buoyant density of the virus isolate in $\mathrm{CsCl}$ was 1.34 $\mathrm{g} / \mathrm{mL}$ as the range of $1.32 \sim 1.37 \mathrm{~g} / \mathrm{mL}$ in the previous report [3]. In physicochemical properties, the virus was stable to chloroform, ether, $50 \sim 70 \%$ ethanol, acidic condition at $\mathrm{pH} 3,0.25 \%$ trypsin $(1: 250)$, heat at $50^{\circ} \mathrm{C}$, but labile to $100 \%$ ethanol, heat at $52 \sim 60^{\circ} \mathrm{C}, 1 \mathrm{M} \mathrm{MgCl}_{2}$ at $50^{\circ} \mathrm{C}$ for $1 \mathrm{~h}$ and $1: 2,000$ formalin $(37 \%)$. It was considered that the virus was labile to the given chemical or heat conditions, if a drop in titers of more than $10^{1.0}$ $\mathrm{TCID}_{50} / \mathrm{mL}$ was recognized after treatment [23]. These properties were agreed to those of FAdVs isolated from IBH which were resistant to chloroform, ether, acidic condition at $\mathrm{pH} 3,0.25 \%$ trypsin and heat at $50^{\circ} \mathrm{C}$ for 60 min [19]. Petek et al. [20, 21] also determined that chicken embryo lethal orphan virus, which belongs to FAdV-1, was resistant to chloroform, ether, $0.25 \%$ trypsin, $50 \%$ ethanol, but labile to $100 \%$ ethanol, heat at $56 \sim 60^{\circ} \mathrm{C}$ for $30 \mathrm{~min}$ and $1 \mathrm{M} \mathrm{MgCl}_{2}$ at $50^{\circ} \mathrm{C}$. Therefore, physicochemical properties of the Korean FAdV isolates to various chemical and heat conditions as well as buoyant density in $\mathrm{CsCl}$, which were unclear before were fully determined, and these properties pertained to common features of FAdV strains. To our knowledge, biological and physicochemical characteristics of the Korean FAdV isolates were first reported in the present study.

All of 4 FAdV isolates were classified as serotype 4 based on the RFLP patterns of hexon genes and whole genomic DNAs, as suggested in the previous papers [10, 16, 22, 24, 26]. They discriminated serotypes among FAdV isolates according to the RFLP patterns of hexon genes by HpaII digestion and those of chromosomes by BamHI digestion. In the present study, the RFLP patterns of hexon genes of the FAdV isolates were derived from the viruses existing in liver tissues of naturally infected chickens, to exclude the results from possible mutations in the genes after passages in cell cultures. Therefore, the RFLP patterns of the hexon genes were distinct enough to classify serotypes of the isolates, which were also confirmed by the RFLP patterns of whole genomes.

Eight viral peptides sized 23 180 kDa were determined in these Korean FAdV-4 isolates. Balamurugan et al. [5] also reported 3 Indian strains of FAdV-4 which had 8 peptide bands ranged 20 107 kDa. Among these, they suggested a peptide with $107 \mathrm{kDa}$ as hexon protein. In these Indian strains, there also were polypeptide bands above $107 \mathrm{kDa}$, which were proposed as precursor polypeptides. On the other hands, Kumar and Chandra [13] reported a strain of Indian FAdV isolated from HPS had 12 peptide bands ranged $13.8 \sim 110 \mathrm{kDa}$, and they supposed a $110 \mathrm{kDa}$-peptide was hexon protein. In the present study, similarly, a peptide band with $110 \mathrm{kDa}$ was regarded as hexon protein, and 2 bands, 160 and $180 \mathrm{kDa}$, as precursor polypeptides as in these Indian strains. When compared to foreign strains, therefore, the Korean FAdV-4 had some disagreements to the peptide bands in numbers and molecular weight. The results, however, can be used as the new information on the peptides of FAdV-4 strains, although these differences should be further elucidated.

\section{References}

1. Abe T, Nakamura K, Tojo H, Mase M, Shibahara T, Yamaguchi S, Yuasa N. Histology, immunohistochemistry, and ultrastructure of hydropericardium syndrome in adult broiler breeders and broiler chicks. Avian Dis 1998, 42, 606-612.

2. Adair BM, Fitzgerald SD. Adenovirus infections; group I adenovirus infections. In: Saif YM, Fadly AM, Glisson JR, McDougald LR, Nolan LK, Swayne DE (eds.). Diseases of Poultry. 12th ed. pp. 252-266, Wiley-Blackwell, Ames, 2008.

3. Adair BM, McFerran JB. Adenoviruses. In: DufourZavala L; American Association of Avian Pathologists (eds.). A Laboratory Manual for the Isolation, Identification, and Characterization of Avian Pathogens. 5th ed. pp. 84-89, American Association of Avian Pathologists, Athens, 2008.

4. Anjum AD, Sabri MA, Iqbal Z. Hydropericarditis syndrome in broiler chickens in Pakistan. Vet Rec 1989, 124, 247-248. 
5. Balamurugan V, Kataria JM, Kataria RS, Verma KC, Nanthakumar T. Characterization of fowl adenovirus serotype-4 associated with hydropericardium syndrome in chicken. Comp Immunol Microbiol Infect Dis 2002, 25, 139-147.

6. Chandra R, Shukla SK, Kumar M, Garg SK. Electron microscopic demonstration of an adenovirus in the hepatocytes of birds experimentally infected with hydropericardium syndrome. Vet Rec 1997, 140, 70-71.

7. Chu KS, Lee JW, Song HJ. Diagnosis of avian adenovirus-associated hydropericardium hepatitis syndrome. Korean J Vet Serv 2007, 30, 313-319.

8. Ganesh K, Raghavan R, Gowda RN, Satyanarayana ML, Suryanarayana VV. Purification and characterization of the aetiological agent of hydropericardium hepatitis syndrome from infected liver tissues of broiler chickens. Trop Anim Health Prod 2002, 34, 7-17.

9. Hess M. Detection and differentiation of avian adenoviruses: a review. Avian Pathol 2000, 29, 195206.

10. Hess M, Raue R, Prusas C. Epidemiological studies on fowl adenoviruses isolated from cases of infectious hydropericardium. Avian Pathol 1999, 28, 433-439.

11. Kim JN, Byun SH, Kim MJ, Kim J, Sung HW, Mo IP. Outbreaks of hydropericardium syndrome and molecular characterization of Korean fowl adenoviral isolates. Avian Dis 2008, 52, 526-530.

12. Kim KS, Ha JS, Kim JH. Occurrence of hydropericardium-hepatitis syndrome in broilers and baeksemis raised in Korea. Korean J Vet Res 2007, 47, 285-290.

13. Kumar R, Chandra R. Studies on structural and immunogenic polypeptides of hydropericardium syndrome virus by SDS-PAGE and western blotting. Comp Immunol Microbiol Infect Dis 2004, 27, 155161.

14. MacLachlan NJ, Dubovi EJ. Fenner's Veterinary Virology. 4th ed. pp. 203-212, Academic Press, San Diego, 2010.

15. Mase M, Mitake $\mathbf{H}$, Inoue T, Imada T. Identification of group I-III avian adenovirus by PCR coupled with direct sequencing of the hexon gene. J Vet Med Sci 2009, 71, 1239-1242.

16. Mazaheri A, Prusas C, Voss M, Hess M. Some strains of serotype 4 fowl adenoviruses cause inclusion body hepatitis and hydropericardium syndrome in chickens. Avian Pathol 1998, 27, 269-276.

17. Meulemans G, Boschmans M, van den Berg TP, Decaesstecker M. Polymerase chain reaction combined with restriction enzyme analysis for detection and differentiation of fowl adenoviruses. Avian Pathol 2001, 30, 655-660.

18. Meulemans G, Couvreur B, Decaesstecker $M$, Boschmans M, van den Berg TP. Phylogenetic analysis of fowl adenoviruses. Avian Pathol 2004, 33, 164-170.

19. Otsuki K, Tsubokura M, Yamamoto H, Imamura M, Sakagami Y. Some properties of avian adenoviruses isolated from chickens with inclusion body hepatitis in Japan. Avian Dis 1976, 20, 693-705.

20. Petek M, Felluga B, Zoletto R. Biological properties of CELO virus: stability to various agents, and electronmicroscopic study. Avian Dis 1963, 7, 38-49.

21. Petek M, Felluga B, Zoletto R, Bersani G. Further studies on CELO virus: Its relationship to the adenovirus group. Arch Virol 1964, 14, 637-649.

22. Raue R, Hess M. Hexon based PCRs combined with restriction enzyme analysis for rapid detection and differentiation of fowl adenoviruses and egg drop syndrome virus. J Virol Methods 1998, 73, 211-217.

23. Rovozzo GC, Burke CN. A Manual of Basic Virological Techniques. pp. 126-152, Prentice-Hall, Englewood Cliffs, 1973.

24. Toro H, Prusas C, Raue R, Cerda L, Geisse C, González C, Hess M. Characterization of fowl adenoviruses from outbreaks of inclusion body hepatitis/hydropericardium syndrome in Chile. Avian Dis 1999, 43, 262-270.

25. Villegas $\mathbf{P}$, Alvarado I. Virus identification and classification. In: Dufour-Zavala L; American Association of Avian Pathologists (eds.). A Laboratory Manual for the Isolation, Identification, and Characterization of Avian Pathogens. 5th ed. pp. 209-216, American Association of Avian Pathologists, Athens, 2008.

26. Zsák L, Kisary J. Grouping of fowl adenoviruses based upon the restriction patterns of DNA generated by BamHI and HindIII. Intervirology 1984, 22, 110114. 